Article

\title{
A Technical Report of the Robust Affordable Next Generation Energy Storage System-BASF Program
}

\author{
Kwo-hsiung Young ${ }^{1,2, *}$, K. Y. Simon $\mathrm{Ng}^{2}$ and Leonid A. Bendersky ${ }^{3}$ \\ 1 BASF/Battery Materials-Ovonic, 2983 Waterview Drive, Rochester Hills, MI 48309, USA \\ 2 Department of Chemical Engineering and Materials Science, Wayne State University, Detroit, MI 48202, USA; \\ sng@wayne.edu \\ 3 Material Measurement Laboratory, National Institute of Standards and Technology, Gaithersburg, MD 20899, \\ USA; leoben@nist.gov \\ * Correspondence: kwo.young@basf.com; Tel.: +1-248-293-7000; Fax: +1-248-299-4228
}

Academic Editor: Andreas Jossen

Received: 28 November 2015; Accepted: 18 January 2016; Published: 1 February 2016

\begin{abstract}
The goal of the Robust Affordable Next Generation Energy Storage System (RANGE)-BASF program is to provide an alternative solution for the energy storage media that powers electric vehicles other than the existing Li-ion battery. With the use of a rare-earth-free metal hydride $(\mathrm{MH})$ as the active negative electrode material, together with a core-shell type alpha-beta nickel hydroxide as the active positive electrode and a sealed pouch design, an energy density of $145 \mathrm{Wh} \cdot \mathrm{kg}^{-1}$ and cost model of $\$ 120 \mathrm{kWh}^{-1}$ are shown to be feasible. Combined with the proven safety record and cycle stability, we have demonstrated the feasibility of using a Ni-MH battery in EV applications.
\end{abstract}

Keywords: nickel-metal hydride (Ni-MH) battery; electrochemistry; hydrogen storage alloys; nickel hydroxide; ionic liquid (IL); alkaline electrolyte; cell package

\section{Introduction}

On 21 August 2013, the US Department of Energy Advanced Research Projects Agency-Energy (ARPA-E) announced an award of \$3,873,537 to BASF under the Robust Affordable Next Generation Energy Storage System (RANGE) program [1]. The program was designed for a two-year period with BASF being the primary award recipient with partners from Wayne State University (WSU), the National Institute of Standards and Technology (NIST), and Strategic Analysis, Inc. (SAI). Dr. Ping Liu was the program director and stated in his review article that his goal for the RANGE program was to develop low-cost and/or high-specific-energy storage redox chemistries [2].

In 1999, $\mathrm{Ni} / \mathrm{MH}$ batteries using an $\mathrm{AB}_{2}$ metal hydride (MH) alloy were used to power EV1, which was the first commercialized EV made by General Motors Auto Co. With a Ni/MH pack of $26.4 \mathrm{kWh}$ onboard, EV1 has a drive range of 160 miles between charges (which may take up to $8 \mathrm{~h}$ ) [3]. The specific energy of $\mathrm{Ni} / \mathrm{MH}$ battery used in EV1 was only about $52 \mathrm{Wh} \cdot \mathrm{kg}^{-1}$. Since then, 15 years of continuous development in the $\mathrm{Ni} / \mathrm{MH}$ technology has substantially improved both specific energy [4] and cycle stability [5]. Ni/MH battery has a relatively high energy density (Wh. $\mathrm{L}^{-1}$ ) but a rather low specific energy (Wh. $\mathrm{kg}^{-1}$ ) when compared to the rival Li-ion battery because of its high density of active materials in the anode (nickel-based alloys versus graphite). MgNi-based $\mathrm{MH}$ alloy is one of the candidates to replace the current rare-earth-metal-based $A_{5}$ and $A_{2} B_{7} M H$ alloys because of the low cost, low density, and high hydrogen storage capacity [6]. However, it also suffers from severe oxidation in the conventional $30 \mathrm{wt} \% \mathrm{KOH}$ electrolyte (AB (MgNi) Old in Figure 1).

Therefore, in order to implement the high-capacity MgNi-based MH alloy in the EV application, a thorough study of the electrolyte is needed. The tasks outlined before the start of the program are illustrated in Figure 2. 


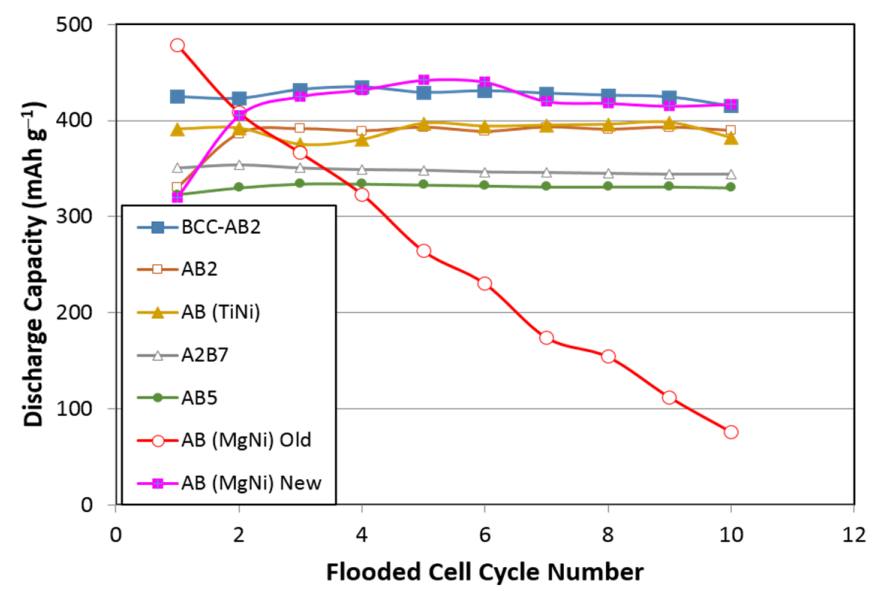

Figure 1. Electrochemical discharge capacity obtained in the flooded cell configuration with a very low discharge current density $\left(4 \mathrm{~mA} \cdot \mathrm{g}^{-1}\right)$ for six commonly used metal hydride $(\mathrm{MH})$ alloys used as active materials in the negative electrode. The mischmetal-based $A_{5}$ alloy is the most used negative electrode material in today's commercial $\mathrm{Ni} / \mathrm{MH}$ batteries. The $\mathrm{AB}(\mathrm{MgNi}) \mathrm{Old}$ was measured with a conventional $6 \mathrm{M} \mathrm{KOH}$, while the $\mathrm{AB}(\mathrm{MgNi}) \mathrm{New}$ was measured with a $1 \mathrm{M} \mathrm{KOH}+1 \mathrm{M}$ $\mathrm{NaOH}$ electrolyte.

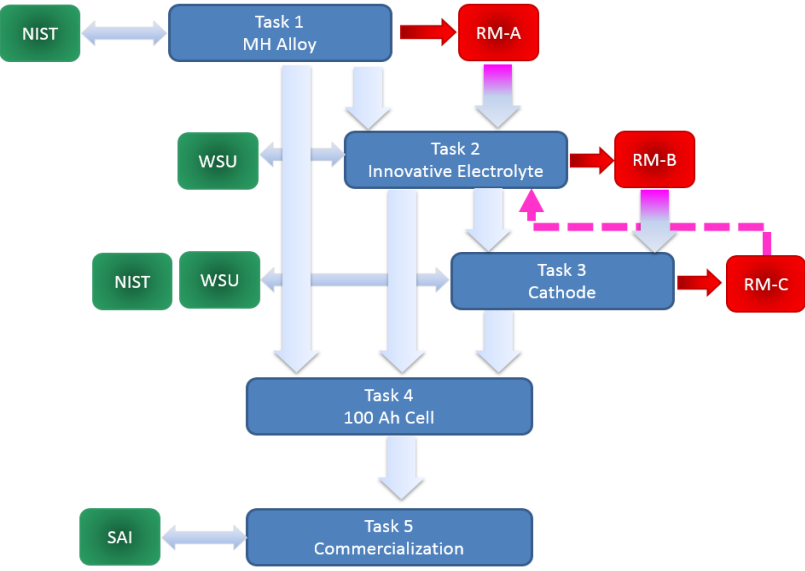

Figure 2. Schematic of tasks (in blue boxes), risk mitigations (RM, in red boxes), and interactions with partners (in green boxes) for the Robust Affordable Next Generation Energy Storage System (RANGE)-BASF program.

The scope of Task 1 focuses on the development of high-capacity MH alloys, which includes $\mathrm{MgNi}, \mathrm{BCC}$, and $\mathrm{Si}$, as shown in Figure 3.

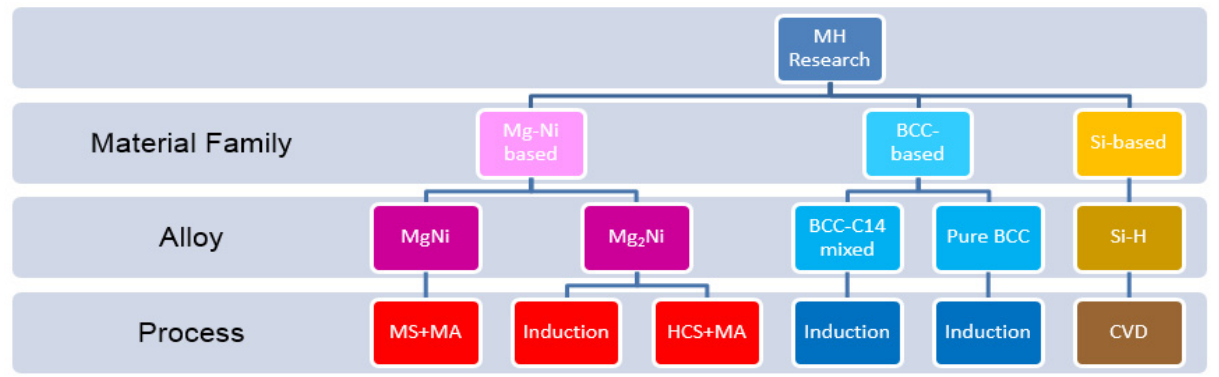

Figure 3. Scope of MH alloy selections in Task 1. MS: melt spin; MA: mechanical alloying; HCS: hydrogen combustion synthesis; and CVD: chemical vapor deposition. 
Task 2 is to develop an alternative electrolyte system to reduce the corrosive nature and possibly to expand the redox reaction voltage window (Figure 4). Task 3 is to develop high-capacity cathode active materials for the conventional alkaline electrolyte and the newly developed organic solvent/ionic-liquid-based electrolyte. Task 4 is to integrate these advanced materials in a 100-Ah cell developed for EV application (C/3 charge and discharge rates). Finally, Task 5 is designed to facilitate the commercialization of the Ni/MH battery for EV application. Three risk mitigation (RM) plans were included: RM-A was to investigate carbon-based (carbon nanotube, graphite, and graphene) anode material; RM-B was to use perovskite oxide as the solid electrolyte; and RM-C was to develop non-hydroxide-based cathode material for the organic electrolyte. As for the contributions from different partners, NIST will support the microstructural analysis in Tasks 1 and 3, WSU will play an important role in Tasks 2 and 3, and SAI will focus on Task 5.

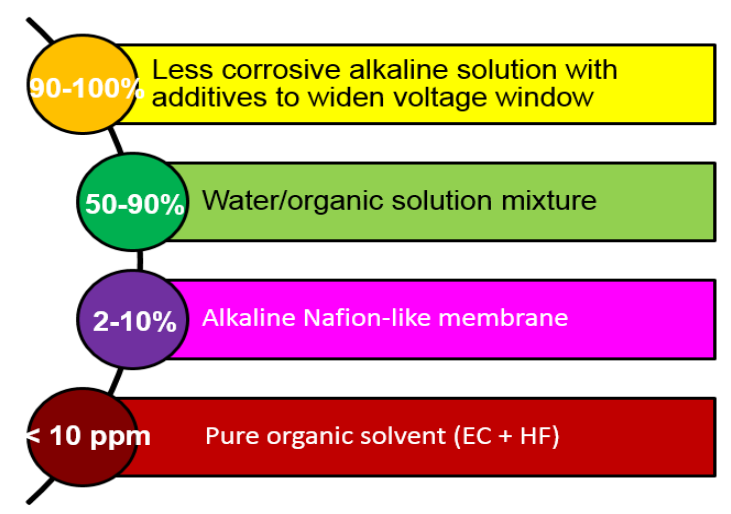

Figure 4. Four main directions for the studies of alternative electrolytes. Percentages in the circles represent the water concentration.

\section{Technical Achievements}

\subsection{Metal Hydride Alloy in Negative Electrode}

In the development of negative electrode (anode), five $\mathrm{MH}$ systems, $\mathrm{MgNi}, \mathrm{Mg}_{2} \mathrm{Ni}, \mathrm{BCC}-\mathrm{C} 14$, pure $\mathrm{BCC}$, and $\mathrm{Si}$, were investigated according to the original plan (Figure 3). Results of capacities are summarized in Table 1. $\mathrm{MgNi}$ (AR3: $\mathrm{Mg}_{52} \mathrm{Ni}_{39} \mathrm{Co}_{3} \mathrm{Mn}_{6}$ ) prepared by a melt-spinning and mechanical alloying (MA) process showed a good low-rate capacity but failed when the discharge current increased to $100 \mathrm{~mA} \cdot \mathrm{g}^{-1}$. We tried five crystalline $\mathrm{Mg}_{2} \mathrm{Ni}$ alloys doped with $\mathrm{Cr}, \mathrm{Co}, \mathrm{Mn}$, and $\mathrm{Si}$ and the electrochemical results were disappointing. The BCC-C14 alloys went through a sequence of composition refinements [7-11] and the final champion, P37 with a composition of $\mathrm{Ti}_{14.5} \mathrm{Zr}_{1.7} \mathrm{~V}_{46.6} \mathrm{Cr}_{11.9} \mathrm{Mn}_{6.5} \mathrm{Co}_{1.5} \mathrm{Ni}_{16.9} \mathrm{Al}_{0.4}$, showed the highest capacity under a $100 \mathrm{~mA} \cdot \mathrm{g}^{-1}$ discharge current, with a comparable cycle stability to $\mathrm{AB}_{5}$ (Figure 5).

Table 1. Electrochemical discharge capacities $\left(\mathrm{mAh} \cdot \mathrm{g}^{-1}\right.$ ) for $\mathrm{MH}$ alloys developed in the RANGE-BASF program. AR3: $\mathrm{Mg}_{52} \mathrm{Ni}_{39} \mathrm{Co}_{3} \mathrm{Mn}_{6}$.

\begin{tabular}{|c|c|c|c|}
\hline Alloy system & Alloy No. & Capacity @8 mA $\cdot \mathrm{g}^{-1}$ & Capacity @100 mA $\cdot \mathrm{g}^{-1}$ \\
\hline $\mathrm{MgNi}$ & AR3 & 501 & 67 \\
\hline $\mathrm{Mg}_{2} \mathrm{Ni}$ & $\mathrm{Mg}_{66} \mathrm{Ni}_{31} \mathrm{Mn}_{3}$ & 18 & 147 \\
\hline BCC-C14 & P12 & 460 & 259 \\
\hline BCC-C14 & P37 & 414 & 400 \\
\hline Pure BCC & P08 & 408 & 340 \\
\hline $\mathrm{Si}$ & CVD $a-S i: H$ & $>3635$ & $>3635$ \\
\hline
\end{tabular}


The transmission electron microscope (TEM) study on a complicated multi-phase BCC-C14 MH alloy (P7) shows clean boundaries between Laves $\mathrm{C} 14, \mathrm{Ti}_{x} \mathrm{Ni}_{y}$ (B2 structure) and BCC structures (Figure 6). This clean phase boundary facilitates the hydrogen diffusion through the bulk of the alloy.

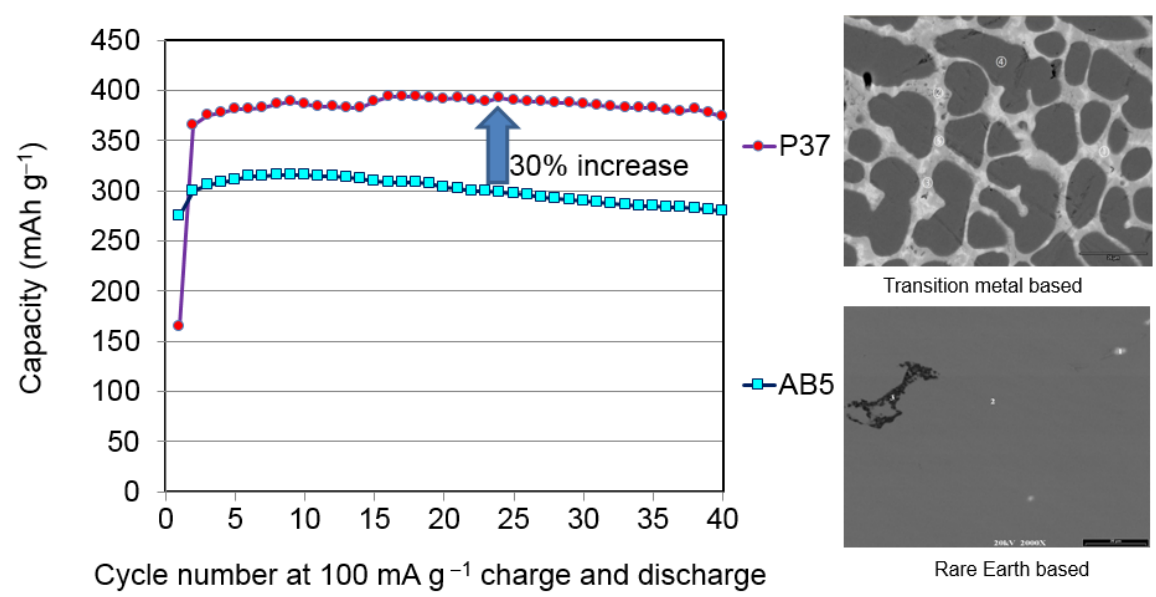

Figure 5. (Left) Comparison of capacities between P37 (BCC-C14 mixed phased) and AB5 (conventional) $\mathrm{MH}$ alloys in the first 40 cycles; and scanning electron microscopy (SEM) micrographs of the (upper right) P37 and (lower right) AB5 corners.
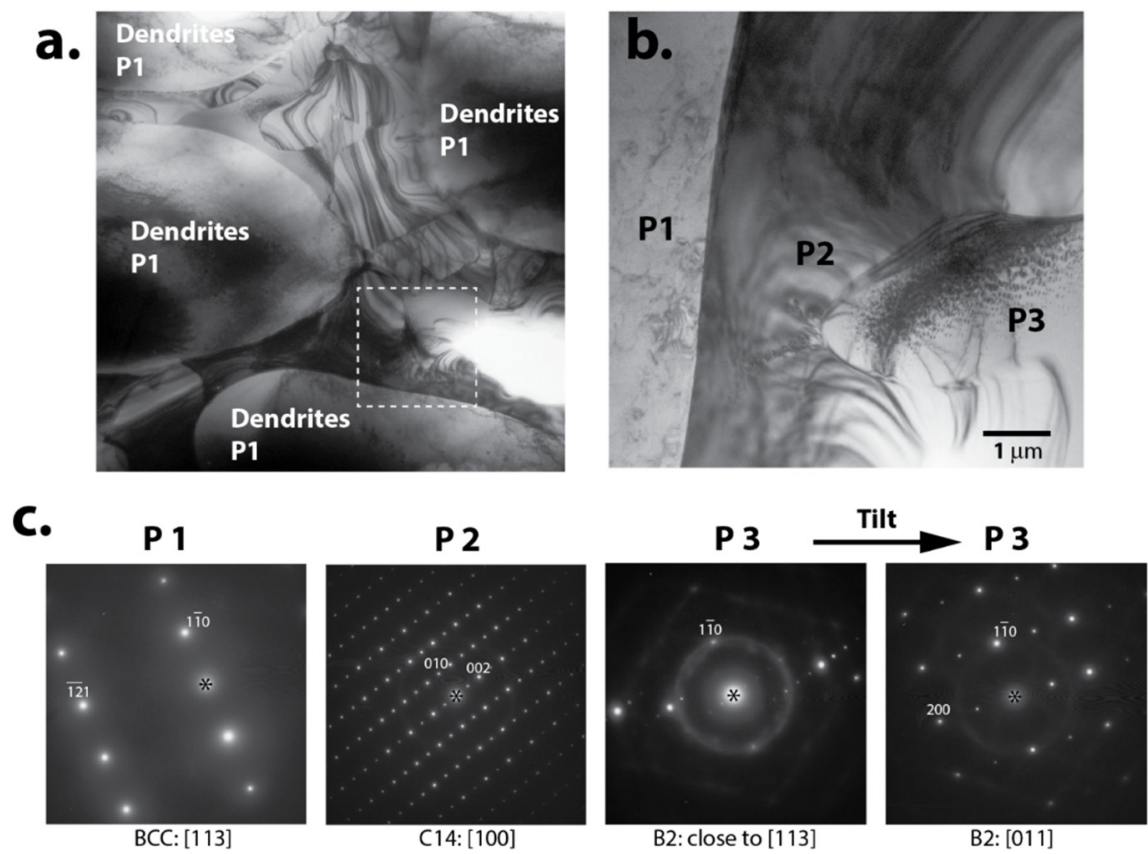

Figure 6. Transmission electron microscope (TEM) study of BCC-C14 alloy (P7): (a) TEM micrograph showing dendrites of phase 1 (P1) and an interdenritic region consisting of two phases shown in enlargement (b) as P2 and P3; (c) selected area electron diffraction patterns from different phases in (b) show that P1 is disordered BCC, P2-Laves C14, and P3-ordered BCC (proved to be B2 after tilting to [011] zone axis.

The further electron backscattering diffraction (EBSD) study of the same sample reveals the crystallographic orientation dependences among various constituent phases (Figure 7), which is more evidence that shows clean grain boundaries among various phases in the alloy.

In the pure BCC MH alloy, the electrochemical discharge capacities increased from $408 \mathrm{mAh} \cdot \mathrm{g}^{-1}$ [12] to $639 \mathrm{mAh} \cdot \mathrm{g}^{-1}$ with optimizations in composition, process, and the 
electrolyte combination [13]. Finally, the Si-based thin film work showed the highest capacity of $3635 \mathrm{mAh} \cdot \mathrm{g}^{-1}$ [14]. Both chemical vapor deposition (CVD) and physical vapor deposition (PVD) were employed to grow amorphous Si thin-films on the substrate (Figure 8). The high capacity and cycle stability of the Si-electrode can be seen in Figure 9.

Besides those five MH systems in Figure 3, we also studied other alternative negative electrode materials and received some unexpected results, such as $370-\mathrm{mAh} \cdot \mathrm{g}^{-1}$ discharge capacity from perovskite oxide and 55-mAh. $\mathrm{g}^{-1}$ discharge capacity from an electrode containing $\mathrm{NiCoMn}(\mathrm{OH})_{6}$.
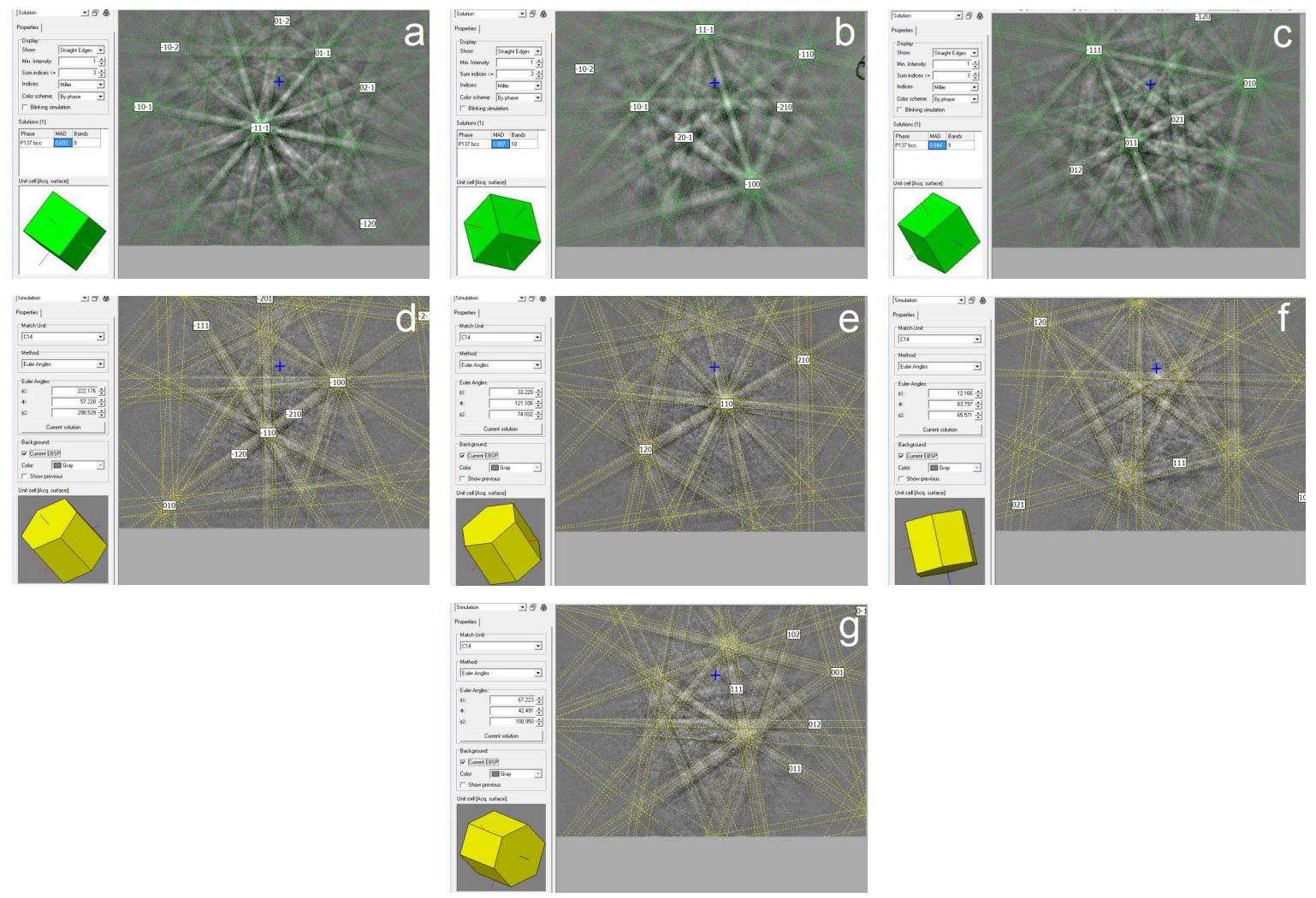

Figure 7. (a-c) Three BCC and (d-g) four C14 electron backscattering diffraction (EBSD) patterns collected from various grains on a typical BCC-C14 alloy (P7) with the computer generated matching orientation information. A few alignments in crystallographic orientation can be identified. For example, the $\left\langle 100>_{\mathrm{BCC}}\right.$ in Figure $7 \mathrm{c}$ is aligned with the $<0001>_{\mathrm{C} 14}$ in both Figure $7 \mathrm{~d}$,e.
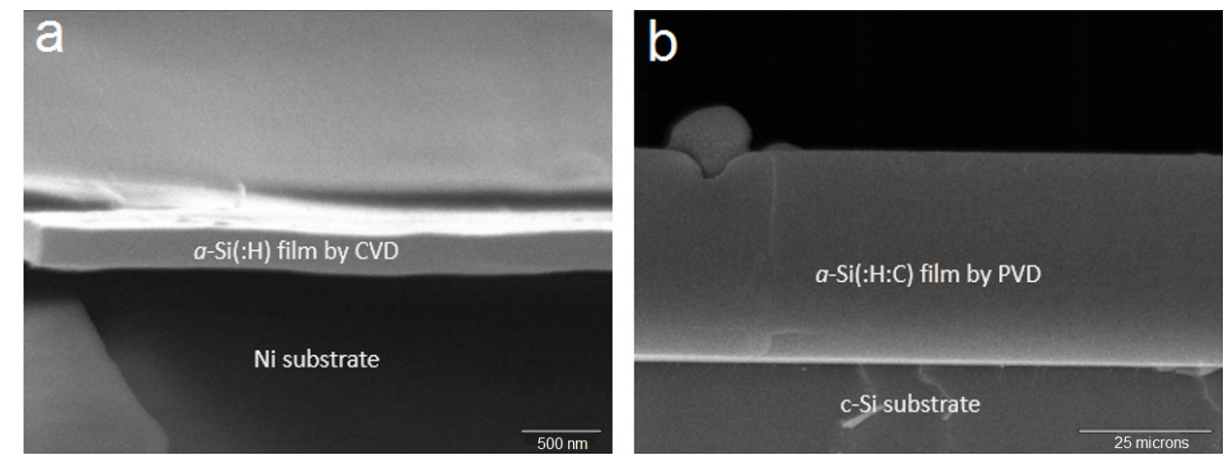

Figure 8. Cross-section SEM micrographs of (a) an $a-\mathrm{Si}: \mathrm{H}$ thin film prepared by CVD and (b) an a-Si:H:C thin-film prepared by physical vapor deposition (PVD). 


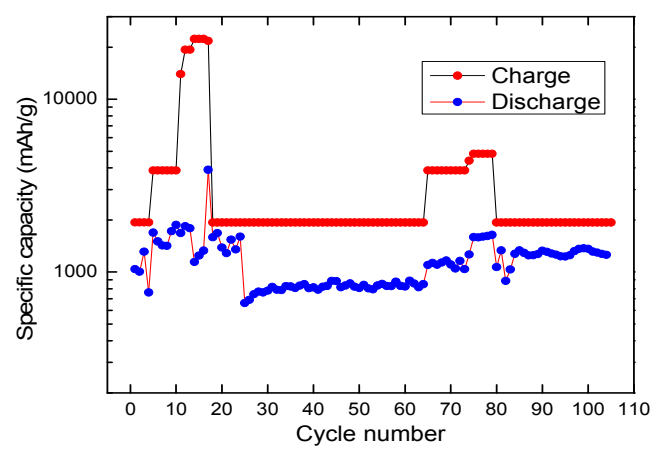

Figure 9. Charge-in and charge-out as functions of cycle number for an $a$-Si:H thin-film electrode prepared by CVD.

\subsection{Development in Electrolyte}

The electrolyte research in RANGE-BASF started from the modifications to the currently used $30 \mathrm{wt} \% \mathrm{KOH}$ aqueous solution with different hydroxides and various salt additives to reduce the corrosion and then expanded to ionic liquid (IL) for the expansion of voltage window, which proved difficult with the current alkaline system. Three other directions highlighted in the original plan (Figure 4) faced different challenges and only exhibited marginal improvement over the currently used electrolyte.

Results from different hydroxides can be summarized by plotting the degradation in the first 15 cycles (normalized to that observed in $30 \mathrm{wt} \% \mathrm{KOH}$ ) in the MgNi alloy versus the conductivity in Figure 10. In general, we found the corrosion capability in various hydroxides in this sequence: $\mathrm{LiOH}$ $>\mathrm{RbOH}>\mathrm{KOH}>\mathrm{NaOH}>\mathrm{CsOH}>\mathrm{TEAOH}$ (tetraethylammonium hydroxide) [15]. The corrosion rate is closely related to the chemical activity of the hydroxide (as indicated by its oxidation potential, for example). TEAOH opens the window to other organic basic chemicals, which are currently under investigation. When a less corrosive electrolyte $(1 \mathrm{M} \mathrm{KOH}+1 \mathrm{M} \mathrm{NaOH})$ was used, the cycle stability of $\mathrm{MgNi}$ alloy improved substantially as seen from Figure 1 (pink curve).

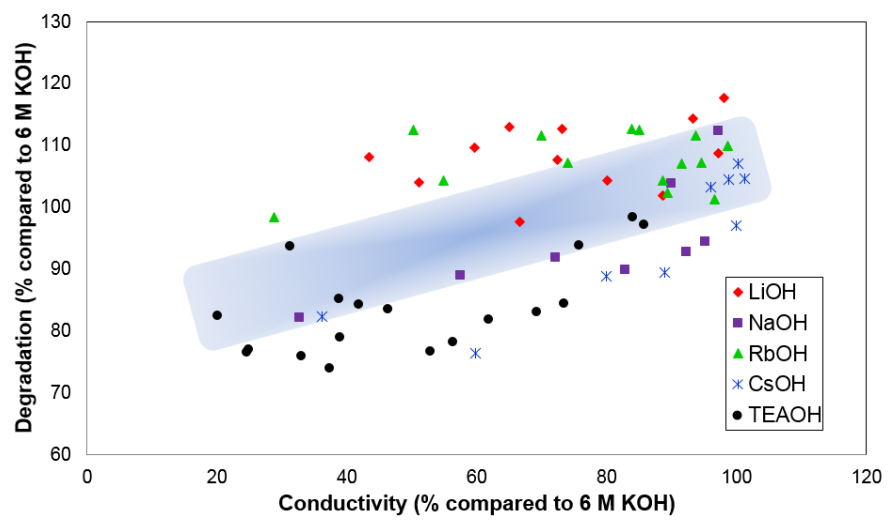

Figure 10. The degradation and conductivity of $\mathrm{MgNi}$ electrodes in various hydroxide as replacement for the $6 \mathrm{M} \mathrm{KOH}$ conventional electrolyte. The shaded area highlights the general trend of data points.

More than 50 soluble salts were tested as additives to the $6 \mathrm{M} \mathrm{KOH}$ electrolyte, and their performance results are summarized in Figure 11. The degradation rate was obtained from the first 15 cycles. The initial capacity and degradation of the $\mathrm{MH}$ alloy correlate well with the reduction potential of the alakine cations and radii of the halogen anions. A synergistic effect between $\mathrm{KOH}$ and some oxyacid salt additives was observed and greatly influenced by the nature of the salt additives [16]. The decrease in the degradation of the electrodes and the increase in the discharge capacity can be sttributed to two sources: a solid film formed on the MH alloy surface and a faster ionic conduction 
in the modified electrolyte [16]. In the end, we identified $\mathrm{NaC}_{2} \mathrm{H}_{3} \mathrm{O}_{2}, \mathrm{KC}_{2} \mathrm{H}_{3} \mathrm{O}_{2}, \mathrm{~K}_{2} \mathrm{CO}_{3}, \mathrm{Rb}_{2} \mathrm{CO}_{3}$, $\mathrm{Cs}_{2} \mathrm{CO}_{3}, \mathrm{~K}_{3} \mathrm{PO}_{4}, \mathrm{Na}_{2} \mathrm{WO}_{4}, \mathrm{Rb}_{2} \mathrm{SO}_{4}, \mathrm{Cs}_{2} \mathrm{SO}_{4}, \mathrm{NaF}, \mathrm{KF}$, and $\mathrm{KBr}$ to be responsible for increasing the corrosion resistance of the $\mathrm{MgNi}$ alloys [16].

The reason why $\mathrm{Ni} / \mathrm{MH}$ has a lower specific energy compared to Li-ion battery is mainly because of the relatively low voltage $(1.3 \mathrm{~V}$ versus $3.7 \mathrm{~V})$ limited by the electrolysis voltage of water. The tandard electrode potential and discharge specific capacity of these two batteries are compared in Table 2 . In order to make a direct comparison, standard hydrogen electrode (SHE) is used as the reference electrode, which is $0.1 \mathrm{~V}$ lower and 3.0 V higher than the commonly used $\mathrm{Hg} / \mathrm{HgO}$ and Li-metal $\left(\mathrm{Li} / \mathrm{Li}^{+}\right)$reference electrodes, respectively. On the cathode side, the Li-ion battery uses the $+3 /+4$ oxidation state change in transition metals, which is $0.2 \mathrm{~V}$ higher than the $+2 /+3$ oxidation state change in Ni/MH battery. The oxygen gas evolution limits the selection of cathode materials in $\mathrm{Ni} / \mathrm{MH}$ battery. Likewise, the selection of anode materials for the Ni/MH battery is limited by the hydrogen gas evolution ( $-0.83 \mathrm{~V}$ versus SHE). The difference in specific capacities between $\mathrm{Li}$-ion and $\mathrm{Ni} / \mathrm{MH}$ batteries is much smaller compared to the difference in cell voltage. Therefore, increasing the cell voltage is one of the primary goals for the electrolyte development in RANGE-BASF. However, in the study with the conventional $30 \mathrm{wt} \% \mathrm{KOH}$ electrolyte, only the addition of the anode materials collected from a commercial Ni-Zn battery showed a $0.2 \mathrm{~V}$ expansion on the anode side. Other Zn- and $\mathrm{Pb}$-containing additives showed no effect in expanding the voltage window of the $\mathrm{KOH}$ electrolyte, which pushed us to pursue the IL.

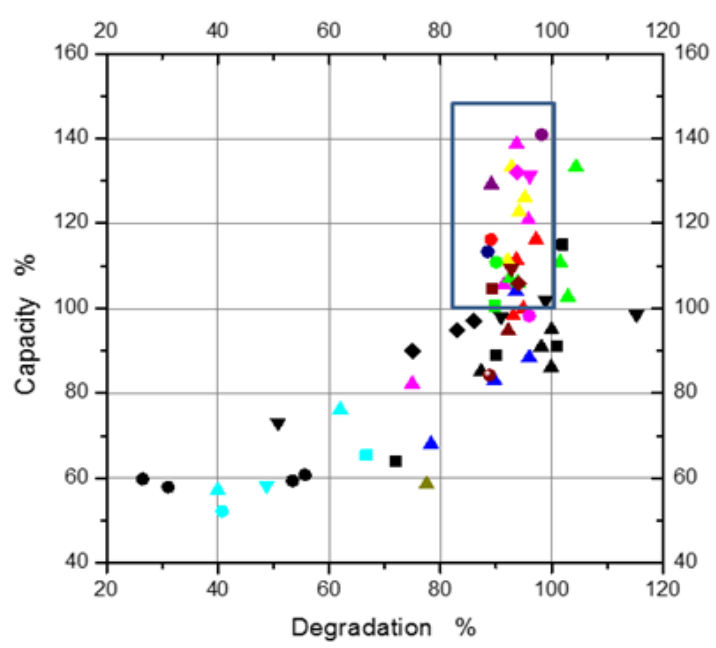

$$
\begin{aligned}
& =\mathrm{LiNO}_{3} \Delta \mathrm{KF} \\
& \text { - } \mathrm{NaNO}_{3}-\mathrm{NaF} \\
& \triangle \mathrm{KNO}_{3} \text { - } \mathrm{LiCl} \\
& \nabla \mathrm{RbNO} \text { - } \mathrm{NaCl} \\
& \Delta \mathrm{C}_{2} \mathrm{H}_{3} \mathrm{O}_{2} \mathrm{~K} \quad \mathrm{KCl} \\
& \text { - } \mathrm{C}_{2} \mathrm{H}_{3} \mathrm{O}_{2} \mathrm{Na} \bullet \mathrm{CsCl} \\
& \text { - Liso } \mathrm{KBr} \\
& \text { - } \mathrm{Na}_{2} \mathrm{SO}_{4} \text { - } \mathrm{LaBr} \\
& \Delta \mathrm{K}_{2} \mathrm{SO}_{4} \Delta \mathrm{KI} \\
& \text { - } \mathrm{Rb}_{2} \mathrm{SO}_{4}-\mathrm{Na}_{2} \mathrm{CO}_{3} \\
& \text { - } \mathrm{Cs}_{2} \mathrm{SO}_{4} \rightarrow \mathrm{K}_{2} \mathrm{CO}_{3} \\
& \text { - } \mathrm{Na}_{2} \mathrm{WO}_{4} \nabla \mathrm{Rb}_{2} \mathrm{CO}_{3} \\
& \mathrm{~K}_{3} \mathrm{PO}_{4} \bullet \mathrm{Cs}_{2} \mathrm{CO}_{3} \\
& \text { - } \mathrm{KIO}_{4}
\end{aligned}
$$

Figure 11. Discharge capacity and degradation of MgNi electrodes in $6 \mathrm{M} \mathrm{KOH}$ electrolyte with different salt additives. Salts in the blue rectangle increase the capacity and reduce the corrosion.

Table 2. Comparison of conventional cathode and anode used in Li-ion and $\mathrm{Ni} / \mathrm{MH}$ batteries. SHE: standard hydrogen electrode.

\begin{tabular}{ccc}
\hline Electrode & Potential (vs. SHE) & Capacity $\left(\mathbf{m A h} \cdot \mathbf{g}^{-1}\right)$ \\
\hline Cathode in Li-ion & $0.7 \mathrm{~V}$ & 230 \\
Cathode in current Ni/MH & $0.5 \mathrm{~V}$ & 280 \\
Cathode in future Ni/MH (Mn) & $1.5 \mathrm{~V}$ & 1116 \\
Anode in Li-ion & $-3.0 \mathrm{~V}$ & 330 \\
Anode in current Ni/MH & $-0.8 \mathrm{~V}$ & 320 \\
Anode in future Ni/MH (Si) & $-1.0 \mathrm{~V}$ & 3635 \\
\hline
\end{tabular}

ILs are liquids consisting exclusively of cations and anions and exhibit superior physicochemical properties such as low melting points, high thermal and electrochemical stability, high ionic conductivity, negligible vapor pressure, and non-inflammability, which make them ideal candidates for electrochemical applications. After screening a few combinations of ILs and anhydrous acids, we 
found that the mixture of aprotic [EMIM][Ac] (1-ethyl-3-methylimidazolium acetate, structure shown in Figure 12) and glacial acetic acid was a suitable candidate to replace the conventional electrolyte (30 $\mathrm{wt} \% \mathrm{KOH}$ in $\mathrm{H}_{2} \mathrm{O}$ ) [17]. Acid is needed in aprotic IL to supply the protons to carry the charge.

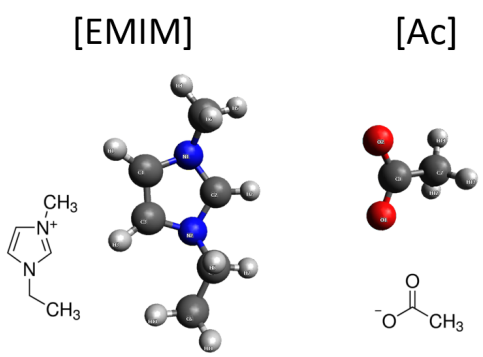

Figure 12. Molecular structure of 1-ethyl-3-methylimidazolium acetate ([EMIM][Ac]) that has been used extensively in the RANGE-BASF program.

A cyclic voltammogram (CV) of an $\mathrm{AB}_{5}$ electrode in $2 \mathrm{M}$ acetic acid in [EMIM][Ac] shows a $0.6 \mathrm{~V}$ separation between the hydride reduction and hydrogen gas evolution peaks (Figure 13a). Using [EMIM][Ac]/Ac mixtures electrolyte, we are able to study the Si-anode in this non-aqueous system since $a$-Si is highly reactive with the $\mathrm{KOH}$ electrolyte [18].
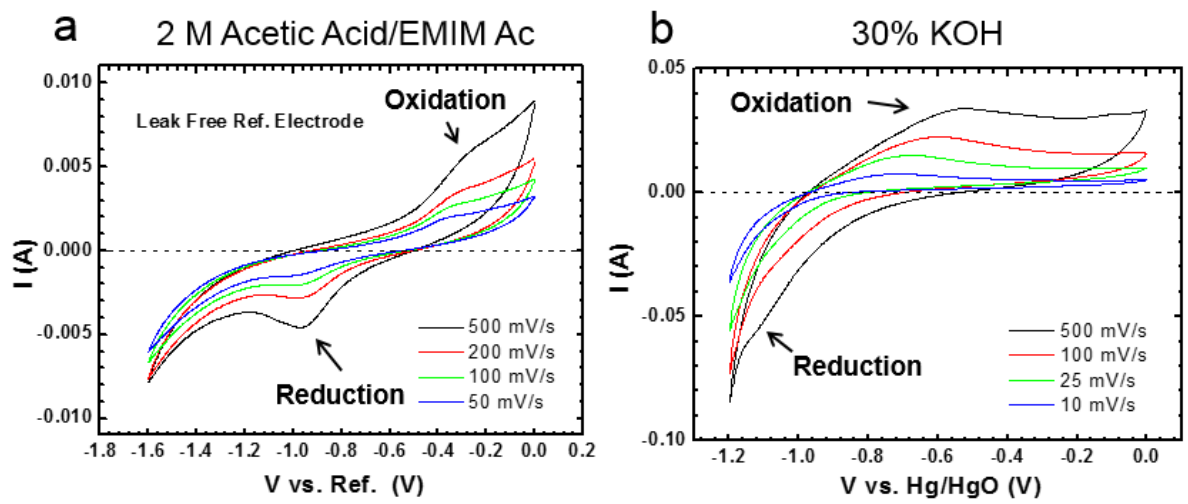

Figure 13. Cyclic voltammetry (CV) graph of an $\mathrm{AB}_{5}$ electrode in: (a) an ionic liquid (IL) (2 M acetic acid in $[\mathrm{EMIM}][\mathrm{Ac}])$; and (b) aqueous electrolytes $(30 \mathrm{wt} \% \mathrm{KOH})$.

Other development efforts in the electrolyte area include adding a Nafion coating on the negative electrode to reduce corrosion, and replacing aqueous electrolyte with solid polymer membrane (300 mAh. $\mathrm{g}^{-1}$, Figure 14a,b) or gel (320 mAh. $\mathrm{g}^{-1}$, Figure $\left.12 \mathrm{c}\right)$, or non-aqueous $1 \mathrm{M}$ triflic acid in PC:DMC (propylene carbonate:dimethyl carbonate) $=1: 1\left(50 \mathrm{mAh} \cdot \mathrm{g}^{-1}\right)$.
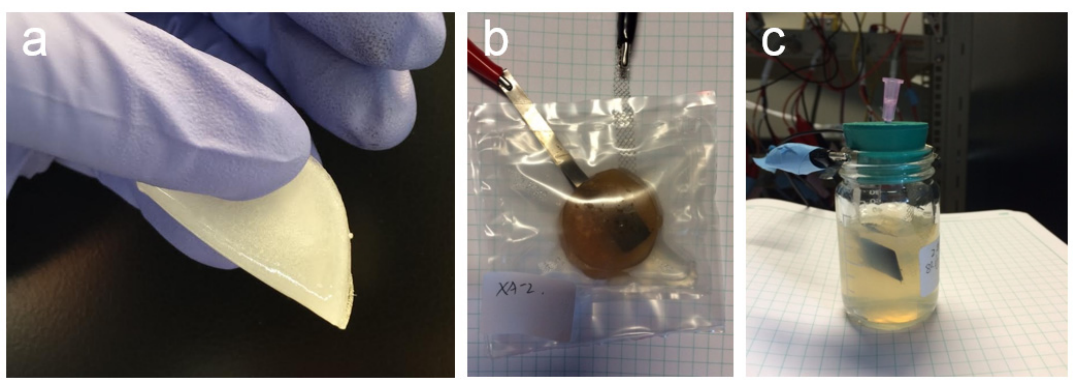

Figure 14. (a,b) A flexible PEO-PVA-KOH- $\mathrm{H}_{2} \mathrm{O}$ gel film; and (c) PVA-KOH gel electrolyte. PEO: polyethylene oxide; and PVA: polyvinel alkahol. 


\subsection{Development in Positive Electrode}

The development work on the positive electrode (cathode) started from the expansion of the oxidation swing window. Because of the limit from the oxygen gas evolution competition, the redox reaction for $\mathrm{Ni}(\mathrm{OH})_{2}$ is conventionally between +2 and +3 oxidation states (Figure 15).

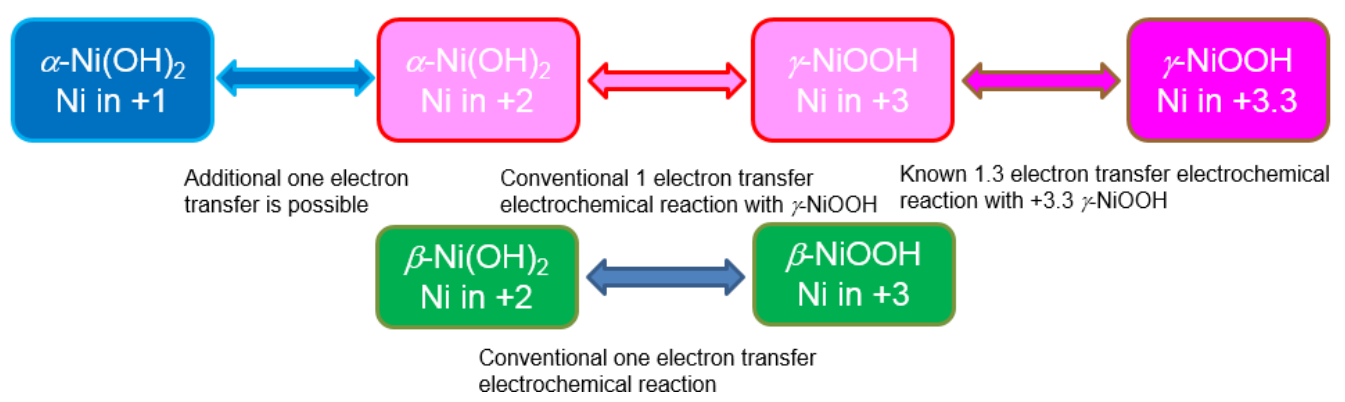

Figure 15. Changes in the oxidation states in $\mathrm{Ni}$ with different chemical reaction. Reactants in green boxes are used in the conventional Ni-based rechargeable batteries, while those in pink boxes are avoided to prevent electrode swelling/disintegration. The one in the blue box is the key element in the high-capacity positive electrode study in the RANGE-BASF program.

The Pourbaix diagram of $\mathrm{Ni}$ shows the $+3 /+4$ redox reaction happens at about $0.2 \mathrm{~V}$ above the oxygen gas evolution potential (Figure 16). The $\gamma-\mathrm{NiOOH}$ is known to have a higher oxidation state (+3.3 or higher) but is still allowed in the aqueous solution [19]. However, transformation from $\beta-\mathrm{Ni}(\mathrm{OH})_{2}$ into $\alpha-\mathrm{Ni}(\mathrm{OH})_{2}$ requires insertion of a water layer between the $\mathrm{NiO}_{2}$ planes, which causes a swelling/disintegration of the positive electrode and is avoided by the addition of $\mathrm{Zn}$ or $\mathrm{Cd}$ [20].

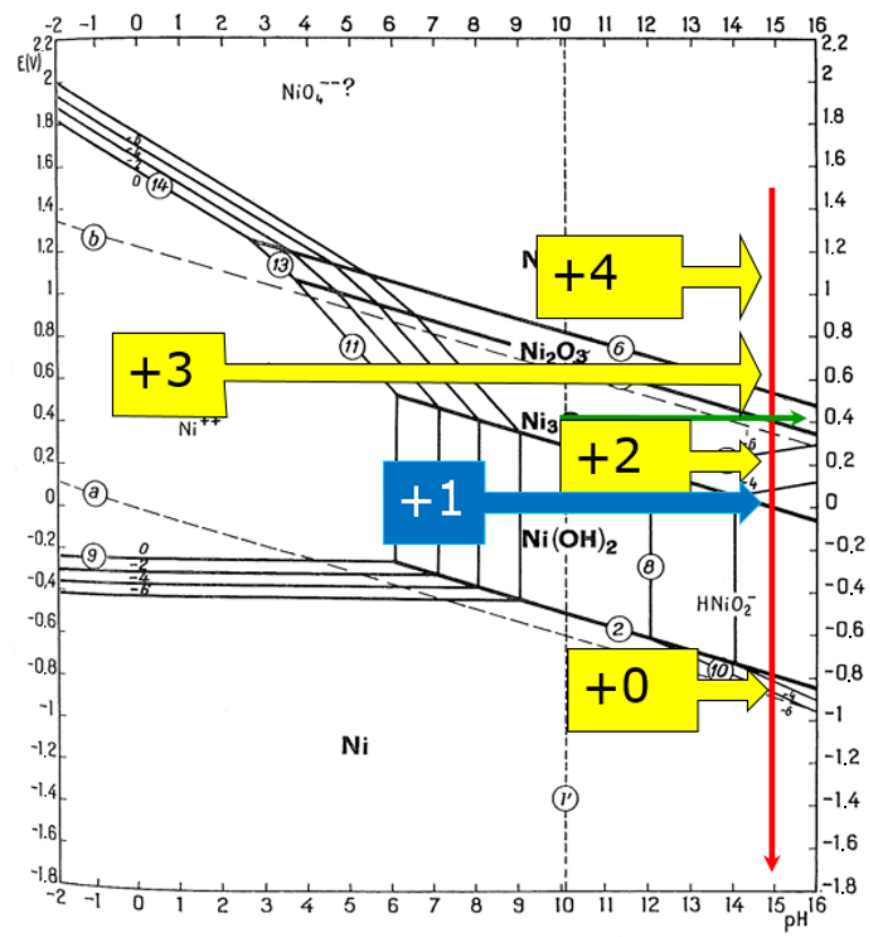

Figure 16. Pourbaix diagram showing different oxidation states of $\mathrm{Ni}$ at different voltages $v$ s. standard hydrogen electrode (SHE). The red line corresponds to the $\mathrm{pH}$ value of the $30 \% \mathrm{KOH}$ electrolyte. Oxidation states in yellow boxes are well-known, while the one in the blue box is the focus of the RANGE-BASF study. 
In the RANGE-BASF program, we developed a continuous process to fabricate core-shell $\alpha-\beta$ $\mathrm{Ni}(\mathrm{OH})_{2}$ (WM12) with a 50\% increase in specific capacity and good cycle stability (Figure 17).

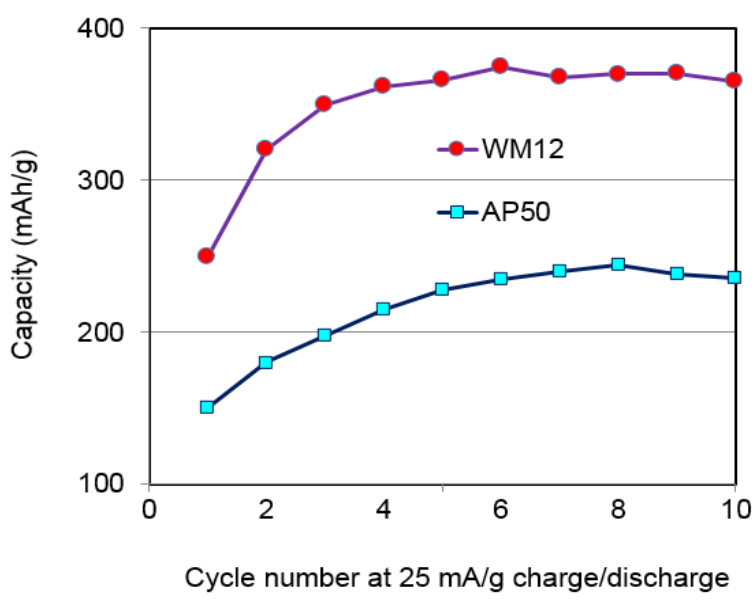

(a)

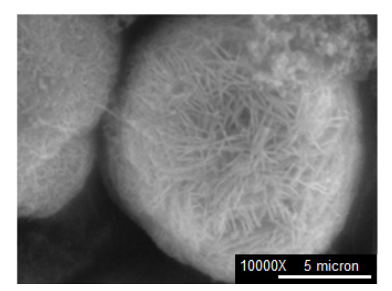

(b)

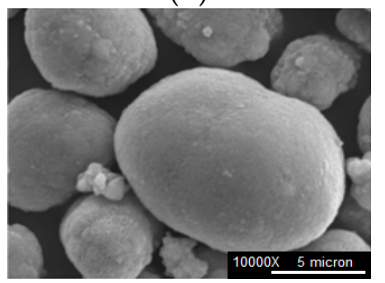

(c)

Figure 17. (a) Capacity comparison between core-shell $\alpha-\beta$ WM12 and conventional $\beta-\mathrm{Ni}(\mathrm{OH})_{2}$ AP50 spherical particles. SEM micrographs of two materials: (b) WM12 and (c) AP50. Instead of a relative smooth surface of AP50, WM12 shows a very rough surface with a high reaction surface area.

The X-ray energy dispersive spectroscopy (EDS)/scanning electron microscopy (SEM) study shows a higher $\mathrm{Al}$ (an $\alpha$-phase promoter) content at the surface (Figure 18).

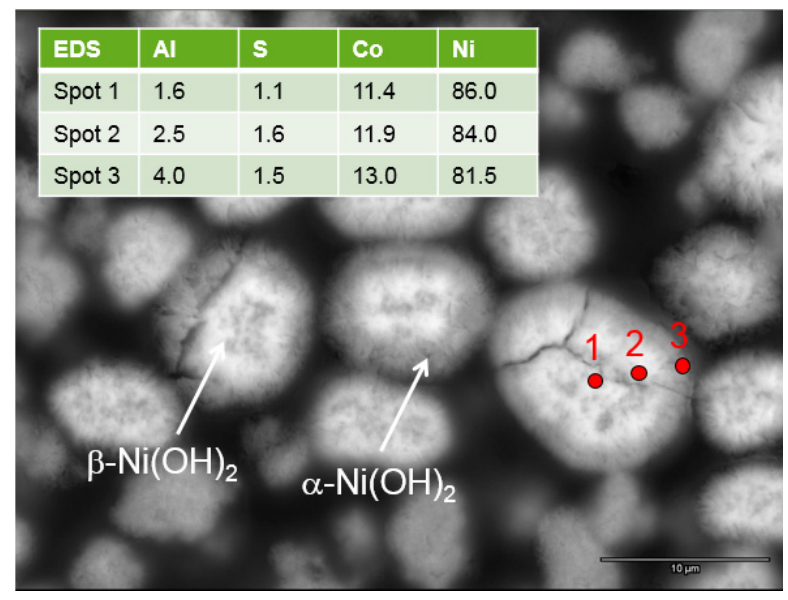

Figure 18. Cross-section SEM micrograph of the continuous process prepared WM12 $\mathrm{Ni}(\mathrm{OH})_{2}$, showing that the core $(\beta)$-shell $(\alpha)$ structure has different Al-contents, as shown in the $\mathrm{X}$-ray energy dispersive spectroscopy (EDS) results in the inset.

A TEM micrograph from the cross-section of a core-shell WM12 Ni(OH $)_{2}$ is shown in Figure 19a. The corresponding electron yields across the diffraction resembling the $X$-ray diffraction $(X R D)$ patterns are shown in Figure 19b to show the microstructure of $\beta$-core and $\alpha$-shell. The as-prepared material is purely $\beta$-phase $\mathrm{Ni}(\mathrm{OH})_{2}$. During activation, the core with less $\mathrm{Al}$ remains the $\beta$-phase and the shell turns into $\alpha$-phase with a higher Al-content. The surface is very fluffy, which allows $\alpha$-phase to grow without disintegration. Besides the continuous process, WSU also developed batch processes to fabricate $\alpha-\mathrm{Ni}(\mathrm{OH})_{2}$ (Table 3). 


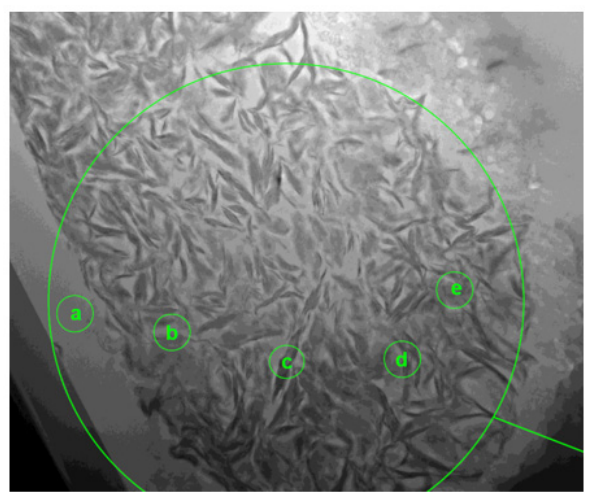

(a) a. Beta-core

b. Between alpha

c. Alpha-shell

d. Alpha-shell

e. Mixture of alpha and beta

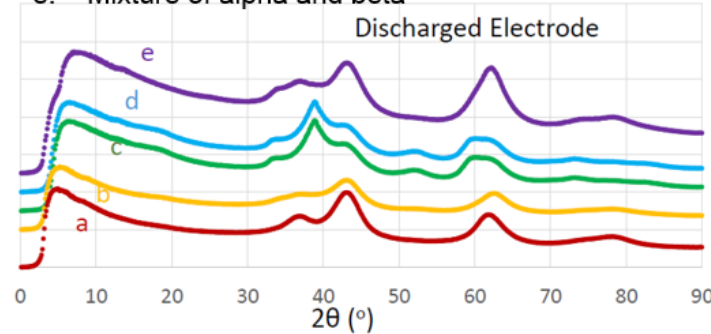

(b)

Figure 19. (a) TEM micrograph of a cross-section of core-shell $\mathrm{WM} 12 \mathrm{Ni}(\mathrm{OH})_{2}$; and (b) the corresponding electron yield across diffraction patterns.

Table 3. Design matrix and results for batch process prepare $\mathrm{Ni}(\mathrm{OH})_{2}$ performed in Wayne State University (WSU).

\begin{tabular}{|c|c|c|c|c|}
\hline Parameter & $\mathrm{Ni}-1$ & $\mathrm{Ni}-2$ & $\mathrm{Ni}-3$ & $\mathrm{Ni}-4$ \\
\hline Preparation & $\begin{array}{c}\text { Single-step } \\
\text { precipitation }\end{array}$ & $\begin{array}{c}\text { Multi-step } \\
\text { precipitation }\end{array}$ & $\begin{array}{l}\text { Homogeneous } \\
\text { precipitation }\end{array}$ & $\begin{array}{c}\text { Homogeneous } \\
\text { precipitation }\end{array}$ \\
\hline Precipitants & $\mathrm{KOH}$ & $\begin{array}{l}\mathrm{NaOH}, \mathrm{Na}_{2} \mathrm{CO}_{3} \\
\mathrm{NH}_{4} \mathrm{OH}, \mathrm{NH}_{4} \mathrm{Cl}\end{array}$ & Urea, Tween-20 & Urea \\
\hline Composition & $100 \% \mathrm{Ni}$ & $86 \% \mathrm{Ni}, 14 \% \mathrm{Al}$ & $86 \% \mathrm{Ni}, 14 \% \mathrm{Al}$ & $86 \% \mathrm{Ni}, 14 \% \mathrm{Al}$ \\
\hline Structure & $\beta-\mathrm{Ni}(\mathrm{OH})_{2}$ & $\alpha-\mathrm{Ni}(\mathrm{OH})_{2}$ & $\alpha-\mathrm{Ni}(\mathrm{OH})_{2}$ & $\alpha-\mathrm{Ni}(\mathrm{OH})_{2}$ \\
\hline Activation cycles & 6 & 5 & 12 & 11 \\
\hline Maximum capacity $\left(\mathrm{mAh} \cdot \mathrm{g}^{-1}\right)$ & 260 & 346 & 305 & 310 \\
\hline
\end{tabular}

Since the material is $\alpha$-phase before cycling, it does not go through the $\beta$ - $\alpha$ transition. Therefore, the integrity of the $\mathrm{Ni}(\mathrm{OH})_{2}$ particle is preserved (Figure 20), and the capacity is very stable (Figure 21). XRD analysis verifies the $\alpha$-phase structure in both the pristine and cycled materials (Figure 22).
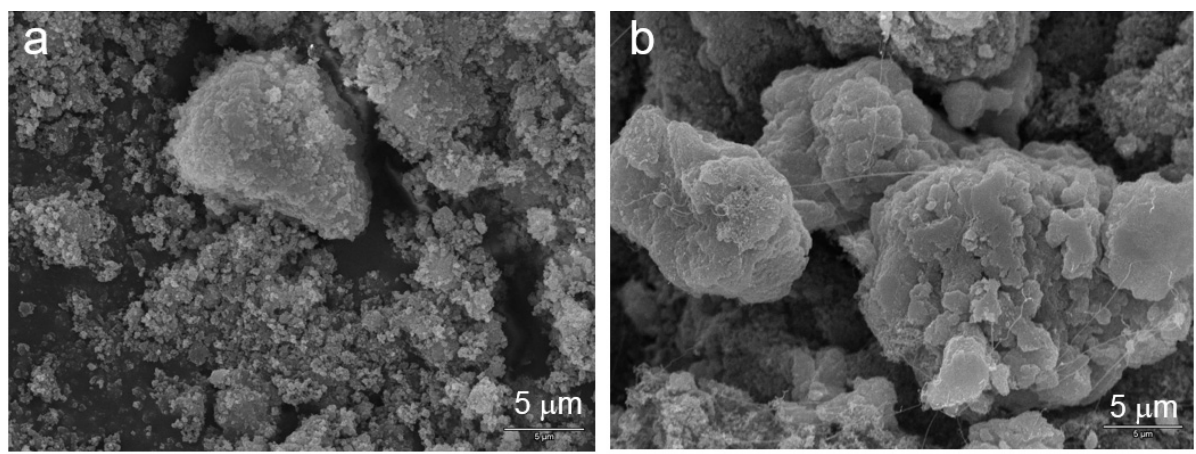

Figure 20. SEM micrographs of (a) pristine and (b) cycled $\alpha-\mathrm{Ni}(\mathrm{OH})_{2}$ prepared by a batch co-precipitation process. 


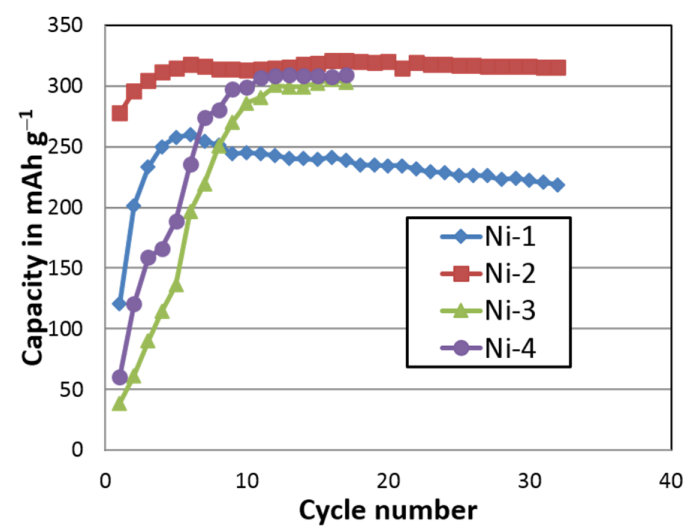

Figure 21. Cycle stability of one $\beta-\mathrm{Ni}(\mathrm{OH})_{2}(\mathrm{Ni}-1)$ and three $\alpha-\mathrm{Ni}(\mathrm{OH})_{2}(\mathrm{Ni}-2, \mathrm{Ni}-3$, and $\mathrm{Ni}-4)$ samples prepared by a batch co-precipitation process.

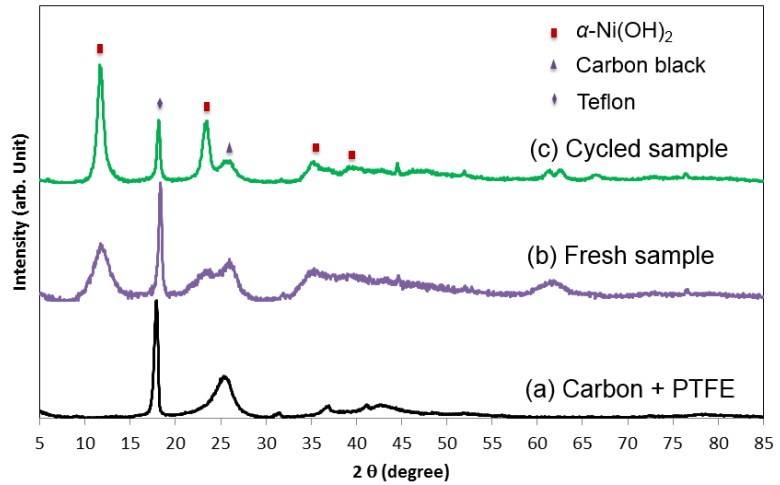

Figure 22. X-ray diffraction (XRD) of (a) the additives, (b) a pristine, and (c) a cycled a $\alpha-\mathrm{Ni}(\mathrm{OH})_{2}$ (Ni-2) prepared by a batch co-precipitation process. From the decrease in the width of the diffraction pattern, the crystallite of $\alpha-\mathrm{Ni}(\mathrm{OH})_{2}$ is found to increase with electrochemical cyclings.

In this program, we also investigated the possibility of further reducing $\alpha-\mathrm{Ni}(\mathrm{OH})_{2}$ into +1 or even lower oxidation state to maximize the range of redox reaction (Figure 16). Discharge into lower potential shows an additional plateau at about $0.8 \mathrm{~V}$ versus standard $\mathrm{AB}_{5}$ negative electrode, which may be related to the +1 oxidation state of $\mathrm{Ni}$, as demonstrated in the literature [21]. The combined number of electron-transfer per $\mathrm{Ni}$ atom may exceed 1 when properly activated (Table 4 ).

Table 4. Discharge specific capacity $(Q)$ and the number of electrons transferred during the redox reaction per $\mathrm{Ni}$ atom $\left(\mathrm{N}_{\mathrm{e}}\right)$ for the first 11 cycles for the $\mathrm{Ni}(\mathrm{OH})_{2}$ samples developed in the RANGE-BASF program. $Q_{\text {Control }}, Q_{\mathrm{S} 1}, Q_{\mathrm{S} 2}$ and $Q_{\mathrm{S} 3}$ are the discharge specific capacities of the control sample $\left(\mathrm{Ni}_{0.91} \mathrm{Co}_{0.045} \mathrm{Zn}_{0.045}(\mathrm{OH})_{2}\right)$, Sample $1\left(\mathrm{Ni}_{0.94} \mathrm{Co}_{0.06}(\mathrm{OH})_{2}\right)$, Sample $2\left(\mathrm{Ni}_{0.85} \mathrm{Co}_{0.05} \mathrm{Al}_{0.10}(\mathrm{OH})_{2}\right)$ and Sample $3\left(\mathrm{Ni}_{0.69} \mathrm{Co}_{0.05} \mathrm{Zn}_{0.06} \mathrm{Al}_{0.20}(\mathrm{OH})_{2}\right)$ for a discharge current density of $25 \mathrm{~mA} \cdot \mathrm{g}^{-1}$, respectively.

\begin{tabular}{|c|c|c|c|c|c|c|c|c|c|c|c|}
\hline Cycle number & 1 & 2 & 3 & 4 & 5 & 6 & 7 & 8 & 9 & 10 & 11 \\
\hline$Q_{\text {Control }}\left(\mathrm{mAh} \cdot \mathrm{g}^{-1}\right)$ & 150 & 180 & 198 & 215 & 228 & 235 & 240 & 243 & 240 & 244 & 238 \\
\hline$N_{\mathrm{e}}$ & 0.59 & 0.71 & 0.78 & 0.85 & 0.90 & 0.93 & 0.95 & 0.96 & 0.95 & 0.97 & 0.94 \\
\hline$Q_{\mathrm{S} 1}\left(\mathrm{mAh} \cdot \mathrm{g}^{-1}\right)$ & 95 & 119 & 141 & 139 & 148 & 149 & 163 & 143 & 245 & 423 & 343 \\
\hline$N_{e}$ & 0.36 & 0.45 & 0.54 & 0.53 & 0.56 & 0.57 & 0.62 & 0.55 & 0.93 & 1.61 & 1.31 \\
\hline$Q_{\mathrm{S} 2}\left(\mathrm{mAh} \cdot \mathrm{g}^{-1}\right)$ & 172 & 216 & 238 & 234 & 243 & 270 & 335 & 635 & 599 & 463 & 259 \\
\hline$N_{\mathrm{e}}$ & 0.69 & 0.86 & 0.95 & 0.94 & 0.97 & 1.08 & 1.34 & 2.54 & 2.39 & 1.85 & 1.03 \\
\hline$Q_{\mathrm{S} 3}\left(\mathrm{mAh} \cdot \mathrm{g}^{-1}\right)$ & 152 & 175 & 190 & 223 & 379 & 530 & 426 & 365 & 329 & 296 & 236 \\
\hline$N_{\mathrm{e}}$ & 0.71 & 0.82 & 0.89 & 1.04 & 1.77 & 2.48 & 1.99 & 1.70 & 1.54 & 1.38 & 1.10 \\
\hline
\end{tabular}




\subsection{Cell Assembly}

Three types of test fixtures were used in the RANGE-BASF program. The first one is a conventional open-air flooded half-cell plastic bag with two or three terminals sandwiched between two pieces of acrylic plates (Figure 23a). The second is a sealed three-terminal Swagelok T-type cell (Figure 23b). The third port (top) can be connected to a reference electrode, a pressure relief value, or a pressure transducer. The third one is a sealed pouch-type full-cell that uses the same materials as those used in the Li-ion pouch cell (Figure 23c).
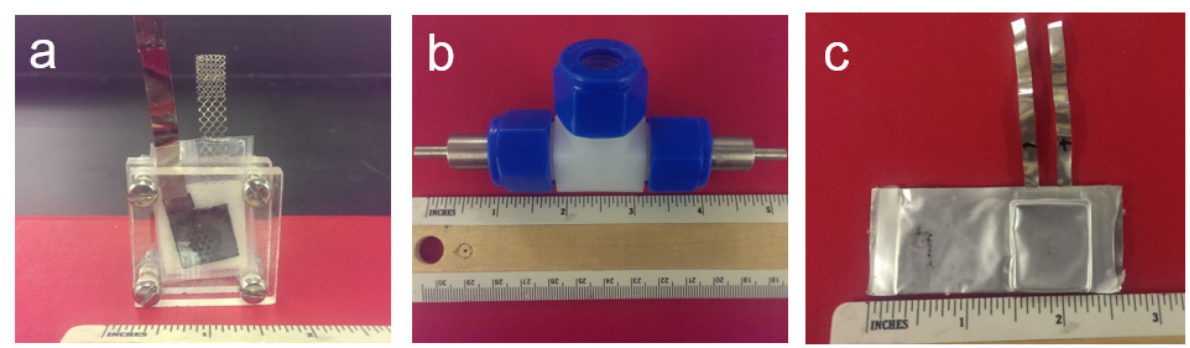

Figure 23. Pictures of a: (a) flooded half-cell; (b) swagelok sealed half-cell; and (c) sealed pouch cell.

The Ni/MH pouch cell has the advantage of easy fabrication and high specific energy density [20]. The development of the pouch cell took about a month, and a cell with a specific energy of $127 \mathrm{Wh} \cdot \mathrm{kg}^{-1}$ was developed in the end with a conventional $A_{5} \mathrm{MH}$ alloy and newly developed WM12 active materials (Figure 24).

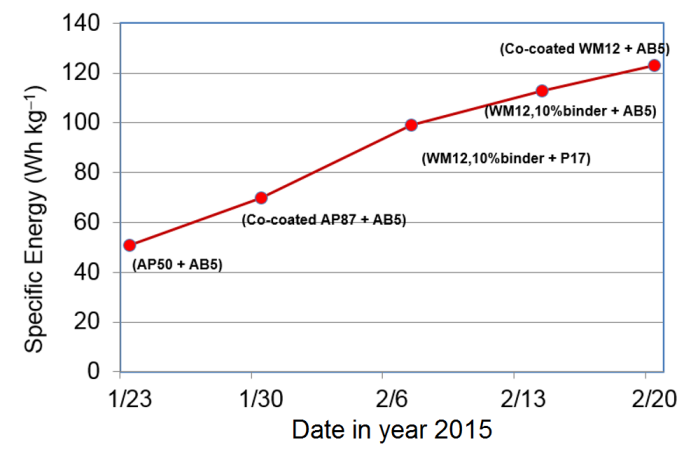

Figure 24. Development timeline of sealed pouch cell showing improvement in the specific energy density from 1 January to 20 February 2015 in BASF-Ovonic.

After applying the newly developed P37 MH alloy, we expect a specific energy of $145 \mathrm{Wh} \cdot \mathrm{kg}^{-1}$ can be realized in a 100-Ah pouch-type Ni/MH battery (Table 5).

Table 5. Design of a 100 Ah pouch-type Ni/MH battery with the cell dimension of $20 \times 12 \times 1.8 \mathrm{~cm}^{3}$ and an N/P ratio of 1.2. Total cell weight is $826 \mathrm{~g}$ and the projected gravimetric and volumetric energy densities are $145 \mathrm{Wh} \cdot \mathrm{kg}^{-1}$ and $278 \mathrm{Wh} \cdot \mathrm{L}^{-1}$, respectively.

\begin{tabular}{cccccc}
\hline Cell component & $\begin{array}{c}\text { Active } \\
\text { weight (g) }\end{array}$ & $\begin{array}{c}\text { Additives } \\
\text { weight (g) }\end{array}$ & $\begin{array}{c}\text { Substrates } \\
\text { weight (g) }\end{array}$ & $\begin{array}{c}\text { Total } \\
\text { weight }(\mathbf{g})\end{array}$ & Area $\left.\mathbf{( c m}^{\mathbf{2}}\right)$ \\
\hline Positive electrode & 303 & 34 & 69 & 406 & 1060 \\
Negative electrode & 316 & 0 & 23 & 339 & 1060 \\
Separator & - & - & - & 13 & - \\
Ni-tab & - & - & - & 5 & - \\
Electrolyte & - & - & - & 12 & - \\
Pouch (Al foil) & - & - & - & & \\
\hline
\end{tabular}




\section{Conclusions}

Throughout this RANGE-BASF program, we discovered a lot of new materials and processes and came up with new directions for future development of the Ni/MH battery, which resulted in 22 US Patent Applications. In our opinion, the advancement of the Ni/MH battery in this one-and-a-half-year period exceeds what had been previously accomplished. The next generation of $\mathrm{Ni} / \mathrm{MH}$ based on the P37, WM12, and pouch design should generate a battery with higher specific energy on a pack-level that considers savings in battery- and thermal- management systems (Figure 25). We will continue to apply these results to the product, and further the research of ILs and novel cathode material areas, which will further improve the specific energy and power of $\mathrm{Ni} / \mathrm{MH}$ to a level competitive with the Li-S battery (Figure 25).

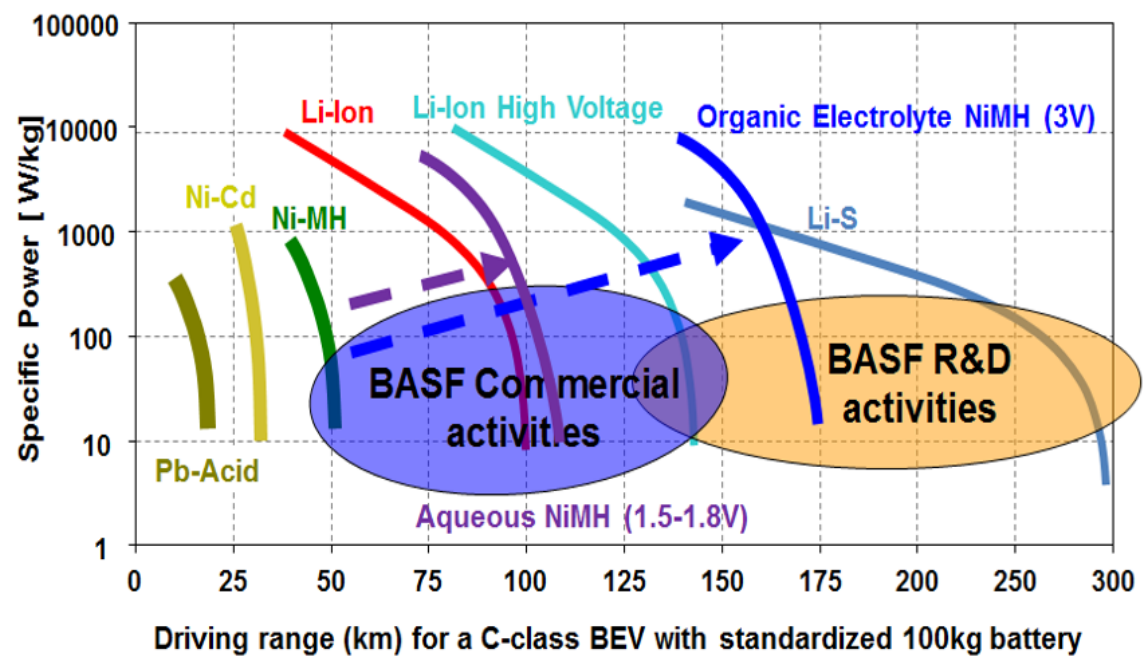

Figure 25. Current and future development goals of the next-generation $\mathrm{Ni} / \mathrm{MH}$ batteries. While the aqueous NiMH uses advance materials developed in the RANGE-BASF program, such as WM12 and P37, the organic electrolyte NiMH will employ IL, the Si-based anode, and the Mn-based cathode.

Acknowledgments: This work was financially supported by Advanced Research Projects Agency-Energy (ARPA-E) under the Robust Affordable Next Generation Energy Storage Systems (RANGE) program (DE-AR0000386). The authors would like to thank the following individuals for their help: Simon Ng, Shuli Yan, Venkateswara Chitturi, Shiuan Chang, Marissa Kerrigan (Wayne State University), Michael A. Fetcenko, Benjamin Reichman, Michael Zelinsky, William Mays, Benjamin Chao, Jean Nei, Baoquan Huang, Tiejun Meng, Lixin Wang, Jun Im, Diana F. Wong, Cristian Fierro, Dennis Corrigan, Taihei Ouchi, David Beglau, Jonathan Tao, Paul Gasiorowski, David Pawlik, Allen Chan, Ryan J. Blankenship, Su Cronogue, Chaolan Hu, Rose Bertolini, Theodore Jurczak (BASF-Ovonic), and Haoting Shen (NIST).

Author Contributions: Kwo-hsiung Young, K. Y. Simon Ng, and Leonid A. Bendersky led research teams for RANGE program in BASF-Ovonic, Wayne State University, and Nation Institute of Standards and Technology, respectively.

Conflicts of Interest: The authors declare no conflicts of interest.

\section{References}

1. High Performance NiMH Alloy for Next-Generation Batteries. Available online: http://arpa-e.energy.gov/ ?q=slick-sheet-project/rare-earth-free-ev-batteries (accessed on 10 November 2015).

2. Liu, P.; Ross, R.; Newman, A. Long-range, low-cost electric vehicles enabled by robust energy storage. MRS Energy Sustain. 2015, 2. [CrossRef]

3. General Motors EV1. Available online: https://en.wikipedia.org/wiki/General_Motors_EV1 (accessed on 12 November 2015).

4. Overview: All Eneloop Batteries 2005-2015. Available online: http://budgetlightforum.com/node/7336 (accessed on 12 November 2015). 
5. Kai, T.; Ishida, J.; Yasuoka, S.; Takeno, K. The Effect of Nickel-Metal Hydride Battery's Characteristics with Structure of the Alloy. In Proceedings of the 54th Battery Symposium in Japan, Osaka, Japan, 7-9 October 2012; p. 210.

6. Young, K.; Nei, J. The current status of hydrogen storage alloy development for electrochemical applications. Materials 2013, 6, 4574-4608. [CrossRef]

7. Young, K.; Nei, J.; Wong, D.F.; Wang, L. Structural, hydrogen storage, and electrochemical properties of Laves phase-related body-centered-cubic solid solution metal hydride alloys. Int. J. Hydrog. Energy 2014, 39, 21489-21499. [CrossRef]

8. Young, K.; Wong, D.F.; Wang, L. Effect of Ti/Cr content on the microstructures and hydrogen properties of Laves phase-related body-centered-cubic solid solution alloys. J. Alloys Compd. 2015, 622, 885-893. [CrossRef]

9. Young, K.; Wong, D.F.; Wang, L. Annealing effect on Laves phase-related body-centered-cubic solid solution alloys. J. Alloys Compd. 2016, 654, 216-225. [CrossRef]

10. Young, K.; Ouchi, T.; Nei, J.; Meng, T. Effect of Cr, Zr, V, Mn, Fe, and Co to the hydride properties of Laves phase-related body-centered-cubic solid solution alloys. J. Power Sources 2015, 281, 164-172. [CrossRef]

11. Young, K.; Wong, D.F.; Nei, J. Effects of vanadium/nickel contents in Laves phase-related body-centered-cubic solid solution metal hydride alloys. Batteries 2015, 1, 34-53. [CrossRef]

12. Young, K.; Ouchi, T.; Huang, B.; Nei, J. Structure, hydrogen storage, and electrochemical properties of body-centered-cubic $\mathrm{Ti}_{40} \mathrm{~V}_{30} \mathrm{Cr}_{15} \mathrm{Mn}_{13} \mathrm{X}_{2}$ alloys ( $\mathrm{X}=\mathrm{B}, \mathrm{Si}, \mathrm{Mn}, \mathrm{Ni}, \mathrm{Zr}, \mathrm{Nb}, \mathrm{Mo}$, and La). Batteries 2015, 1 , 74-90. [CrossRef]

13. Young, K.; Ouchi, T.; Meng, T.; Nei, J. Studies in molybdenum/manganese content in the duel body-centered-cubic phased metal hydride alloys. Unpublished work. 2016.

14. Meng, T.; Young, K.; Beglau, D.; Yan, S.; Zeng, P.; Cheng, M.M. Hydrogenated amorphous silicon thin film anode for proton conducting batteries. J. Power Sources 2016, 302, 31-38. [CrossRef]

15. Yan, S.; Young, K.; Nei, J.; Rotarov, D.; Ng, K.Y.S. Studies in various hydroxides used as electrolyte in Ni/MH batteries. Batteries 2016, 2, to be submitted for publication.

16. Yan, S.; Young, K.; Ng, K.Y.S. Effects of salt additives to the $\mathrm{KOH}$ electrolyte used in $\mathrm{Ni} / \mathrm{MH}$ batteries. Batteries 2015, 1, 54-73. [CrossRef]

17. Meng, T.; Young, K.; Wong, D.F.; Nei, J. Ionic liquid-based non-aqueous electrolyte for nickel metal hydride batteries. Unpublished work. 2016.

18. Kiani, A.; Venkatakrishnan, K.; Tan, B. Maskless lithography using patterned amorphous silicon layer induced by femtosecond laser irradiation. NSTI Nanotech 2010, 2, 276-279.

19. Corrigan, D.A.; Bendert, R.M. Effect of coprecipitated metal ions on the electrochemistry of nickel hydroxide thin films: Cylic voltammetry in $1 \mathrm{M} \mathrm{KOH.} \mathrm{J.} \mathrm{Electrochem.} \mathrm{Soc.} \mathrm{1989,} \mathrm{136,} \mathrm{723-728.} \mathrm{[CrossRef]}$

20. Young, K.; Yasuoka, S. Capacity degradation mechanisms in nickel/metal hydride batteries. Batteries $2016,2$. [CrossRef]

21. Bonneviot, L.; Cai, F.X.; Che, M.; Kermarec, M.; Legendre, O.; Lepetit, C.; Olivier, D. Preparation of mono- or zerovalent nickel by single or successive one-electron-transfer steps in the photoreduction of silica-supported nickel catalysts. J. Phys. Chem. 1987, 91, 5912-5921. [CrossRef]

(C) 2016 by the authors; licensee MDPI, Basel, Switzerland. This article is an open access article distributed under the terms and conditions of the Creative Commons by Attribution (CC-BY) license (http:/ / creativecommons.org/licenses/by/4.0/). 